Article

\title{
Biochemical and Structural Insights into the Winged Helix Domain of P150, the Largest Subunit of the Chromatin Assembly Factor 1
}

\author{
Joëlle Ayoub ${ }^{1,2,3}$, Martina Buonanno ${ }^{1} \mathbb{D}$, Anna Di Fiore ${ }^{1}$, Giuseppina De Simone ${ }^{1, *(\mathbb{D}}$ \\ and Simona Maria Monti ${ }^{1, * \mathbb{D}}$
}

check for updates

Citation: Ayoub, J.; Buonanno, M.; Di Fiore, A.; De Simone, G.; Monti, S.M. Biochemical and Structural Insights into the Winged Helix Domain of P150, the Largest Subunit of the Chromatin Assembly Factor 1. Int. J. Mol. Sci. 2022, 23, 2160. https:// doi.org/10.3390/ijms23042160

Academic Editor: Fabio Altieri

Received: 11 January 2022

Accepted: 12 February 2022

Published: 15 February 2022

Publisher's Note: MDPI stays neutral with regard to jurisdictional claims in published maps and institutional affiliations.

Copyright: (C) 2022 by the authors. Licensee MDPI, Basel, Switzerland. This article is an open access article distributed under the terms and conditions of the Creative Commons Attribution (CC BY) license (https:// creativecommons.org/licenses/by/ $4.0 /)$
1 Institute of Biostructures and Bioimaging, Consiglio Nazionale delle Ricerche (IBB-CNR), Via Mezzocannone, 16, 80134 Naples, Italy; ayoubjoelle@hotmail.com (J.A.); martina.buonanno@cnr.it (M.B.); anna.difiore@cnr.it (A.D.F.)

2 Department of Environmental, Biological and Pharmaceutical Sciences and Technologies, University of Campania Luigi Vanvitelli, 81100 Caserta, Italy

3 Medical Laboratory-Molecular Biology, Saint George Hospital Medical Center, Rmeil-Youssef Sursok Street, Beirut 166378, Lebanon

* Correspondence: giuseppina.desimone@cnr.it (G.D.S.); simonamaria.monti@cnr.it (S.M.M.); Tel.: +39-081-25-34579 (G.D.S.); +39-081-25-34583 (S.M.M.)

\begin{abstract}
The Chromatin Assembly Factor 1 is a heterotrimeric complex responsible for the nucleosome assembly during DNA replication and DNA repair. In humans, the largest subunit P150 is the major actor of this process. It has been recently considered as a tumor-associated protein due to its overexpression in many malignancies. Structural and functional studies targeting P150 are still limited and only scarce information about this subunit is currently available. Literature data and bioinformatics analysis assisted the identification of a stable DNA binding domain, encompassing residues from 721 to 860 of P150 within the full-length protein. This domain was recombinantly produced and in vitro investigated. An acidic region modulating its DNA binding ability was also identified and characterized. Results showed similarities and differences between the P150 and its yeast homologue, namely Cac-1, suggesting that, although sharing a common biological function, the two proteins may also possess different features.
\end{abstract}

Keywords: human P150; CAF-1; CHAF1A; DNA binding; EMSA; human diseases

\section{Introduction}

From yeast to human, genomic DNA is well packaged into a compact and ordered entity named nucleosome, the single unit of chromatin [1,2]. This repeating entity is formed by double-stranded DNA (145-147 bp) wrapped around an octamer of histones (a duplicate of $\mathrm{H} 2 \mathrm{~A}, \mathrm{H} 2 \mathrm{~B}, \mathrm{H} 3$, and $\mathrm{H} 4$ ) [3]. Nucleosomes undertake additional condensation stages to form the final level of compactness, leading to the chromatid of chromosome [4,5]. Despite the compactness, chromatin is known to be a dynamic structure able to unwrap during cellular processes (transcription, DNA replication, and repair) [6-8]. The transition between the wrapping and unwrapping state of the nucleosomes requires the involvement of different complexes known as histone chaperones [7]. Firstly described as preventers of histone-DNA aggregation, these proteins are able to bind histones, shield their positive charges, and avoid the unspecific DNA interactions [9-11]. More recently, histone chaperones were found to play an important role in guiding the specific nucleosome assembly path [12]. Most of them are conserved in eukaryotes and are classified based on their binding capacities (H3/H4 or H2A/H2B chaperones) $[13,14]$. Chromatin assembly reaction occurs in two steps: the addition of $\mathrm{H} 3-\mathrm{H} 4$ dimers onto the DNA occurs during the first step, while H2A-H2B dimers are added later on during the process $[15,16]$. One of the major actor orchestrating the addition of $\mathrm{H} 3 / \mathrm{H} 4$ histones during DNA replication 
and repair is the Chromatin Assembly Factor 1 (CAF-1) [17-20], a three-subunit protein complex functionally conserved within eukaryotes [21-23]. The role of CAF-1 is not only restricted to nucleosome assembly, but also to chromatin silencing and heterochromatin integrity $[16,24,25]$. Due to its involvement into nuclear processes, CAF-1 affects cell fate decision and epigenetic control of gene expression [26]. In agreement with its role in DNA replication and repair, CAF-1 protein levels correlate with cell proliferation and cancer prognosis [27-30] and its dysregulation has been linked to human diseases [31,32].

CAF-1 has been found in H. sapiens, D. melanogaster, M. musculus, C. elegans, S. cerevisiae, and $A$. Thaliana and consists of three subunits in a 1:1:1 ratio in all these species [21-23,33,34]. In humans, the subunits forming CAF-1 were named according to the molecular weight based on their gel migration, i.e., P150, P60, and P48 [17], whereas the same counterparts in yeast were referred to as Cac-1, Cac-2, and Cac-3 (Cac, chromatin-assembly complex) [35].

Among the three subunits, yeast Cac-1 has been the most investigated, and the reported results highlight its importance from a functional point of view. This protein, which consists of 606 residues, contains Cac-2 [36-38] and Cac-3 interacting domains [36,37,39], a proliferating cell nuclear antigen (PCNA) interacting region $[40,41]$, in addition to DNA [36,42] and histone binding domains [36,38] (Figure 1). A first DNA binding domain, identified within a $\mathrm{K} / \mathrm{E} / \mathrm{R}$ rich domain (KER) [43], is located at the N-terminal part of the protein and predicted to adopt a coiled-coil structure. While no specific DNA sequence was identified for the binding, an optimal DNA length of at least 40 bp was suggested [43]. A second DNA binding domain, with a micromolar binding affinity, was identified in the C-terminal region of Cac-1, encompassing residues 520-606. This region was found to adopt a winged helix domain (WHD) structure characterized by four helices, two antiparallel strands, and a long wing loop. It has structural similarities with some WHD-containing proteins [44-47], but also some structural differences compared to canonical ones, such as the presence of a fourth helix [42]. Cac-1 WHD binds DNA in a sequence-independent manner consistently with its transitory functional role. Moreover, it binds different lengths of DNA through electrostatic interactions occurring between its positively charged residues and DNA phosphate groups [42]. Investigation on mutagenized WHD revealed its involvement, together with PCNA, in recruiting and stabilizing CAF-1 at the replication forks in yeast and mouse cells [42]. Finally, the histone binding domain, which contains part of an acidic stretch enriched in E/D (ED) amino acids [36,48], is involved in the interaction with histones $[49,50]$. Remarkably, this region has a regulatory mechanism on WHD, thus affecting the DNA binding ability of Cac-1 [38].

Here, we focused our attention on P150 (also referred as CHAF1A), the largest subunit of the human CAF-1 complex. This protein was first cloned by Kaufman and coworkers in 1995 [51] and later sequenced by Dong and coworkers [52]. It consists of 956 amino acids and is subject to phosphorylation [53]. Similarly to the yeast homologue, P150 has a leading role in nucleosome assembly as highlighted upon depletion and mutation experiments [26]. From a functional point of view, the P150 sequence can be divided into two main regions: the N-terminal one, encompassing residues 1 to 310 which is involved in nucleolar functions [27], and the region encompassing residues 311 to 956, which is necessary and sufficient for nucleosome assembly [51] (Figure 1). P150 N-terminal region is necessary for the localization of different proteins such as nucleophosmin and nucleolin, and its loss is lethal in vivo [27]. It contains four major identified regions: a PEST domain [51,54], three domains interacting respectively with HP1 (Heterochromatin Protein 1) [55-57], SUMO proteins (Small Ubiquitin-like MOdifier) [26,58], and PCNA (proliferating cell nuclear antigen) [59] (Figure 1). Notably, residues 1-310 and 855-956 corresponding to the $\mathrm{N}$ - and C- terminal parts of P150 are absent in Cac-1. On the contrary, the region 311-854 of P150 is conserved in the yeast homologue, where it maintains the same function [51]. Differently from Cac-1, for which many studies have been so far carried out [9,60-62], structural and functional studies targeting P150 are still very limited. However, most of the described Cac-1 regions were conserved in P150, allowing the identification of the homologous domains in the human protein (Figure 1) [43]. 


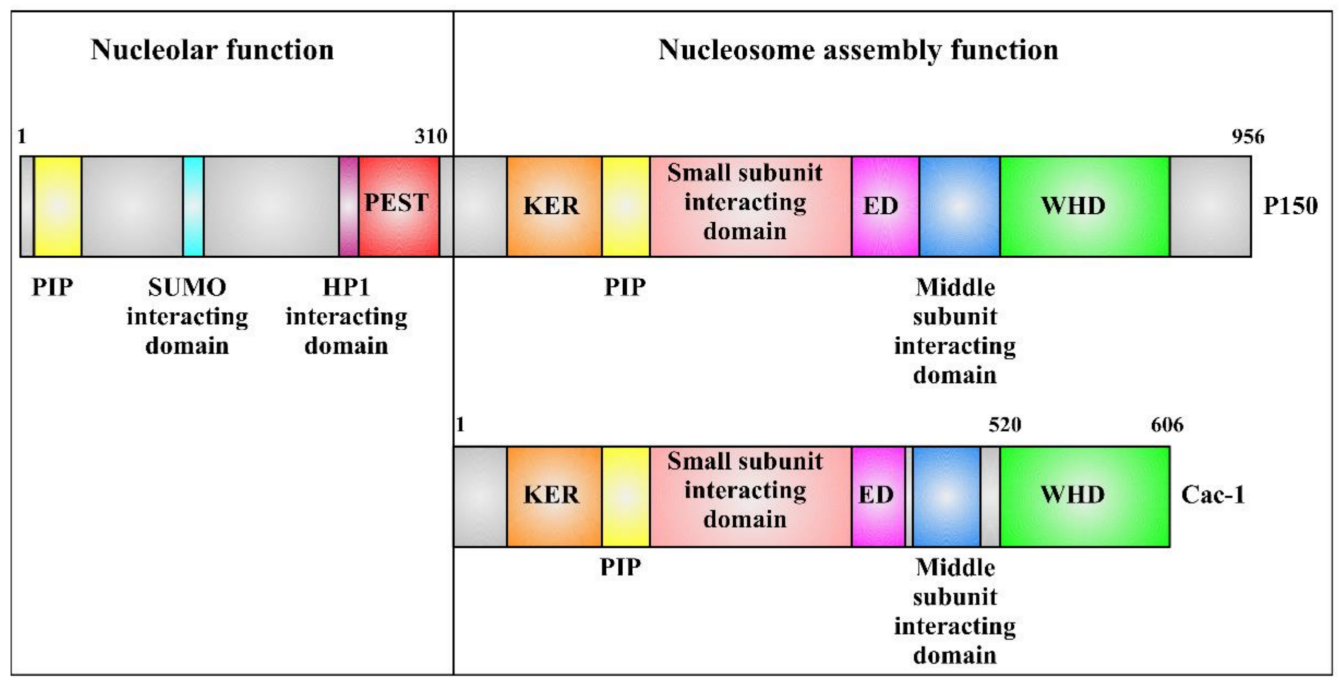

Figure 1. Schematic representation of P150 and Cac-1 components. The N-terminal region of P150 (residues 1-310) contains a PCNA interacting peptide (PIP) that has a strong activity in vitro, a SUMO protein interacting domain, an HP1 interacting region, and a PEST domain. The C-terminal region of P150 (residues 311-956) shows a domain organization similar to Cac-1. Both proteins contain a KER region, a PIP which is mainly responsible for maintaining the in vivo interaction with PCNA [40], the small subunit interacting domain, the ED sequence, the middle subunit interacting domain, and a WHD [43].

Recently, Zhang and coworkers identified a DNA-binding domain in human and mouse P150, corresponding to the Cac-1 WHD, and proved its ability to bind 58 dsDNA [42]. Here, following a multidisciplinary approach, we further investigated this domain and identified a regulatory region of its DNA binding activity. Results highlighted both similarities and differences between the P150 and Cac-1, suggesting that, although sharing a common biological function, the two proteins could adopt a different mechanism of action.

\section{Results}

\subsection{Design and Chemico-Physical Characterization of P150 WHD Domain}

Zhang and coworkers identified the region 727-854 of human P150 as the one corresponding to Cac-1 WHD [42]. Interestingly, Phyre 2 [63], an online software able to predict and analyze protein 3D structures, identified residues 723-824 of P150 as belonging to a stable WHD similar to the one present in the Cockayne syndrome group B protein 1 [64]. Taking together these findings, in order to cover the whole P150 WHD, the protein region encompassing residues 721-860 (hereafter referred as P150721-860) was designed, cloned, expressed, and subsequently purified (Figure S1A). Briefly, P150 $721-860$ gene was cloned into pETM13 vector, allowing the expression of the protein with a His tag at its C-terminal part. Optimized expression in LB was achieved in E. coli BL21(DE3)pLysS strain at $16{ }^{\circ} \mathrm{C}$ with $1 \mathrm{mM}$ isopropyl-thio-D-glactosidase (IPTG). Upon three steps of purification, a purity level greater than $95 \%$ with a final yield of $2.5 \mathrm{mg} / \mathrm{L}$ of growth medium was achieved. Mass spectrometry analyses were carried out to confirm protein identity and purity. Results (Figure 2A) showed one main peak at 16,967 Da corresponding to P150 ${ }_{721-860}$ lacking the starting N-terminal methionine $\left(\mathrm{MW}_{\text {theoretical }}=16,967 \mathrm{Da}\right)$. This excision, due to the methionylamino peptidase [65], is a widely described phenomenon for recombinant proteins expressed in E. coli $[66,67]$.

The secondary structure content of $\mathrm{P} 150_{721-860}$ was assessed by circular dichroism (CD). Results showed negative molar ellipticity values at $208 \mathrm{~nm}$ and $222 \mathrm{~nm}$ in addition to a positive ellipticity below $198 \mathrm{~nm}$ (Figure 2B) indicative of the presence of $\alpha$-helices. The reduced magnitude of the negative ellipticity at $222 \mathrm{~nm}$ highlighted the contribution of 
$\beta$-sheets [68], thus suggesting the occurrence of both $\alpha$-helical and $\beta$-sheet secondary structures, as expected for WHD proteins $[42,69]$. Thermal stability was assessed by CD following changes in ellipticity at $222 \mathrm{~nm}$ when heating up the protein from $20{ }^{\circ} \mathrm{C}$ to $90{ }^{\circ} \mathrm{C}$. Experiments revealed a melting point at $40{ }^{\circ} \mathrm{C}$ (Figure S2A). Notably, the secondary structure of $\mathrm{P} 150_{721-860}$ was almost fully recovered once the sample returned to its initial temperature (Figure S2B).
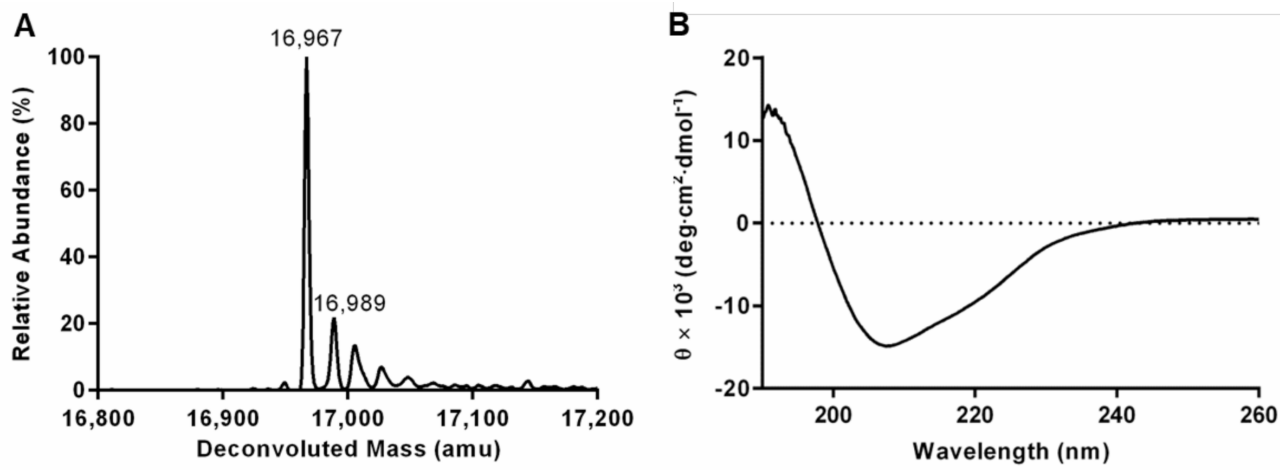

Figure 2. Biochemical features of $\mathrm{P} 150_{721-860}$. (A) Deconvoluted mass spectrum of $\mathrm{P} 150_{721-860}$. The experimental molecular weight corresponds to the polypeptide lacking the initial methionine and comprehensive of the (His) ${ }_{6}$-tag. (B) Far-UV CD spectrum of $\mathrm{P}^{150} 0_{721-860}$ recorded in $1 \mathrm{mM}$ Tris- $\mathrm{HCl}$, $\mathrm{pH} 7.5$, at a protein concentration of $7 \mu \mathrm{M}$ at $20{ }^{\circ} \mathrm{C}$.

The quaternary structure of P150 $721-860$ was investigated by SEC-MALS-QELS [70], revealing that in solution, the protein is a monomer with a molecular weight of $17.5 \mathrm{KDa}$ $( \pm 0.1 \%)$ (Figure 3$)$ in agreement with previously reported results by Mattiroli and coworkers for the isolated Cac-1 WHD [38]. On the contrary, Liu and coworkers showed, by fluorescence anisotropy, that Cac-1 forms a dimer in solution through the C-terminus experiments, and highlighted the influence of buffer composition on the oligomerization state of the protein [48]. Thus, to explore putative effects of ionic strengths on the quaternary structure of $\mathrm{P}^{150_{721-860}}$, LS analyses were carried out at different concentration of $\mathrm{NaCl}[71,72]$. Our results showed that either at $150 \mathrm{mM}$ or $500 \mathrm{mM} \mathrm{NaCl}, \mathrm{P} 150_{721-860}$ is monomeric (Figure S3).

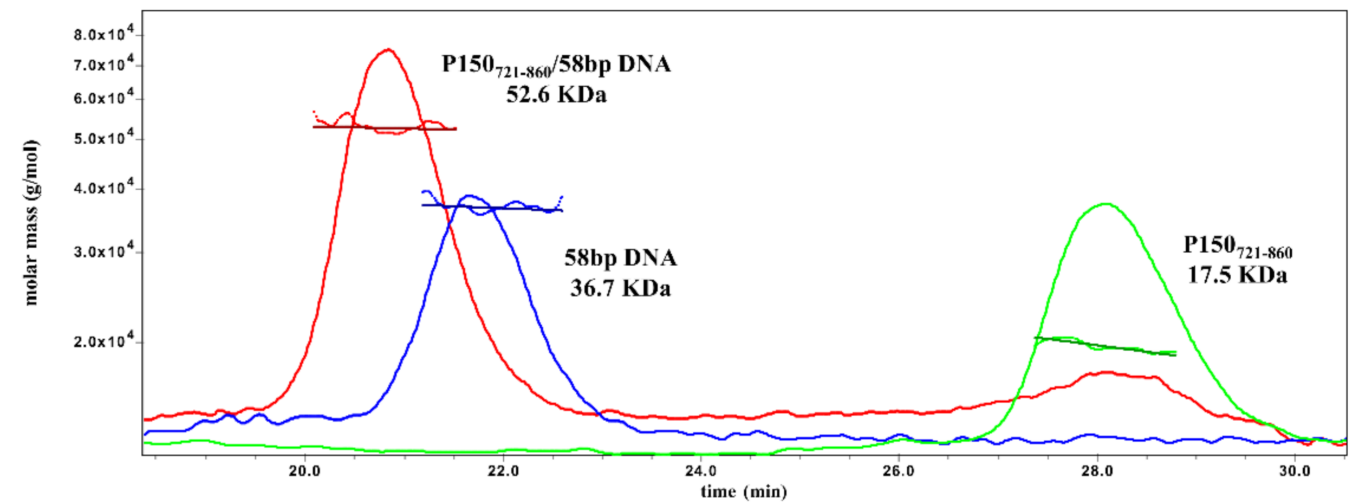

Figure 3. Molar mass of $\mathrm{P}^{150_{721-860}}$, ds58 DNA, and P150 $_{721-860}$ / ds58 DNA complex by SEC-MALSQELS analysis. Overlay of light scattering chromatograms of recombinant $\mathrm{P} 150_{721-860}$ (green line), ds58 DNA (blue line), and P150 $721-860 /$ ds58 DNA complex (red line) samples. The molar mass of each sample is reported. Runs were performed in $20 \mathrm{mM}$ Tris- $\mathrm{HCl}, 150 \mathrm{mM} \mathrm{NaCl}, \mathrm{pH} 7.5$.

\subsection{P150 $121-860$ Binds dsDNA}

Electrophoretic mobility shift assay (EMSA) was carried out to explore the propensity of $\mathrm{P} 150_{721-860}$ to bind DNA. Firstly, we investigated whether $\mathrm{P} 150_{721-860}$ showed preferences in binding DNA with different base composition (AT- or GC-rich) or length (16 and 
58 dsDNA). Obtained results highlighted that $\mathrm{P} 150_{721-860}$ is able to bind dsDNA no matter the composition (Figure S4) and length (Figure S5), consistently with previously reported results performed on Cac-1 [42].

Subsequently, by fitting the data using a nonlinear regression, a $K_{D}$ value of $10.4 \pm 0.5 \mu \mathrm{M}$ was estimated (Figure 4), in agreement with the DNA dissociation constant determined for Cac-1 WHD [42]. The stoichiometry of binding was evaluated by light scattering experiments. Upon incubation of an excess of P150 $721-860$ over 58 bp dsDNA (molar ratio of 3.2:1, P150721-860: dsDNA 58 bp), a complex in a 1:1 molar ratio was clearly identified (Figure 3).
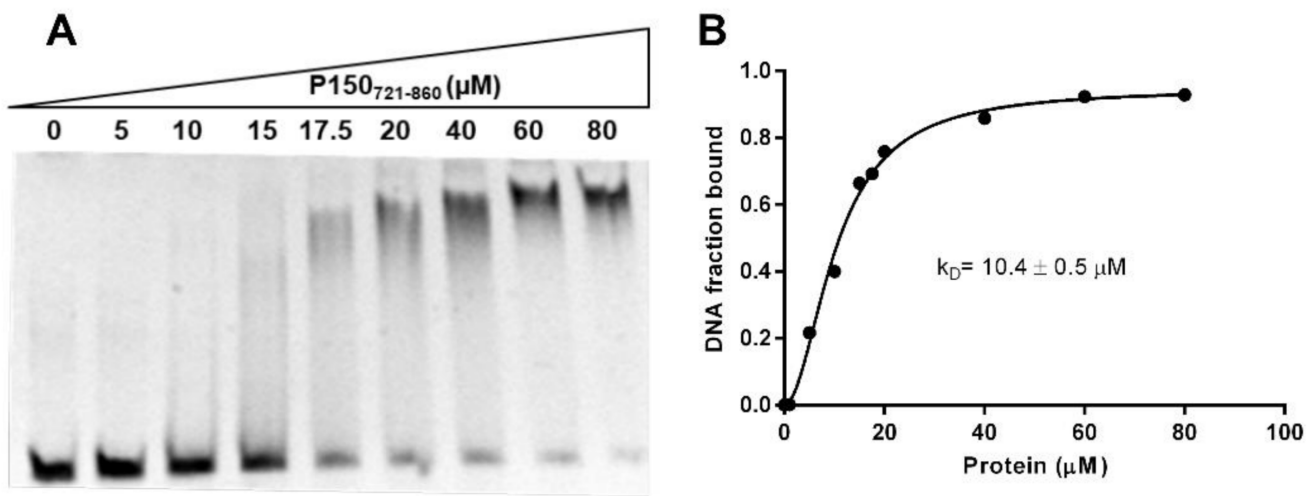

Figure 4. DNA binding ability of $P 150_{721-860}$ to $58 \mathrm{bp}$ dsDNA assessed by EMSA. (A) $1 \mu \mathrm{M} 58 \mathrm{bp}$ dsDNA was incubated with increasing concentration of $\mathrm{P}^{150_{721-860}}$. Gel was stained with Sybr Gold prior to visualization with UV light. (B) The density value of each band quantified by ImageJ was analyzed by Graph Pad-Prism, Version 7.

\subsection{ED Domain Modulates DNA Binding to P150 $721-860$}

In yeast, the ED region enriched in glutamic and aspartic acids constitutes part of the histone binding interface of Cac-1 $[38,43,48]$. In absence of histones, the acidic residues of this region make intramolecular interactions with the basic residues of WHD, masking the DNA binding activity of CAF-1 [36,38]. As revealed by inspecting the sequence, this acidic region is also present in P150 located at the N-terminal part of the WHD here investigated (Figure 1). With the aim to explore whether the described inhibitory mechanism is preserved in P150, a new construct was designed extending the length of $\mathrm{P} 150_{721-860}$ at the N-terminal region to incorporate the acidic domain. Accordingly, a new construct, hereby named as P150575-860, was obtained cloning residues from 575 to 860 of P150 in pETM13 (Figure S1B). The recombinant protein was successfully produced in E. coli, purified, and investigated for its ability to bind DNA. EMSA was carried out incubating the same quantities of $58 \mathrm{bp}$

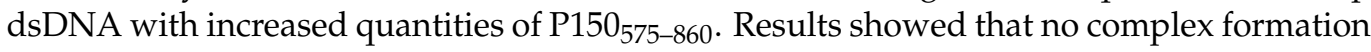
was detected, highlighting that, despite the presence of the WHD, the DNA binding activity of P150 is hindered by the presence of the ED stretch. These data confirm that, similarly to what was observed for Cac-1, in the human subunit, the ED domain modulates the DNA binding activity of WHD (Figure S6).

\section{Discussion}

During DNA replication and DNA repair, the histone chaperone CAF-1 actively orchestrates nucleosome assembly, interacting with replisome and depositing $\mathrm{H} 3-\mathrm{H} 4$ directly onto newly synthetized DNA $[73,74]$. CAF-1 plays pivotal roles in maintaining genome stability; thus, any dysregulation of the complex and its subunits can likely cause alteration in the genome. Nevertheless, biochemical and structural studies on the proteins of the complex are rather limited, with few functional studies carried out only recently [36,38,42]. These investigations led to the development of models suggesting how the three different subunits work in the assembly. Notably, most of these studies have been carried out on S. cerevisiae proteins and results were then translated to the human system $[36,38,42,43]$. 
Here, we report the first detailed biochemical and structural characterization of a P150 DNA binding region and its regulatory mechanism. Starting from preliminary data previously obtained by Liu's group [42], we expressed and purified the putative WHD of P150, namely $\mathrm{P}^{150_{721-860}}$. We demonstrated, by light scattering experiments, that in solution, P150 $721-860$ keeps a monomeric structure independently of ion strength. Literature data on this point are rather controversial; indeed, Mattiroli and coworkers, in agreement with our results, reported a monomeric structure for the isolated Cac-1 WHD [38], whereas the crystallographic structure of the same protein determined by Liu and coworkers highlighted a dimeric arrangement [48]. Interestingly, the same authors reported that homodimerization does not occur when changing buffer composition [48].

Consistently with its biological role, $\mathrm{P} 150_{721-860}$ binds DNA with different base composition (AT- and GC-rich) and lengths (dsDNA 16 and $58 \mathrm{bp}$ ) with a binding affinity in the micromolar range, in accordance with values already reported for WH proteins such as isolated Cac-1 $\left(\mathrm{K}_{\mathrm{D}}=2 \mu \mathrm{M}\right)$ [42], Ash2L $\left(\mathrm{K}_{\mathrm{D}}=12 \mu \mathrm{M}\right)$ [75], FoxM1 $\left(\mathrm{K}_{\mathrm{D}}=7 \mu \mathrm{M}\right)$ [76], and $\operatorname{Rtt106}\left(\mathrm{K}_{\mathrm{D}}>20 \mu \mathrm{M}\right)$ [77]. The absence of a sequence specificity and the low DNA binding affinity are in line with the necessity of a conserved mechanism of CAF-1 to bind replicated or repaired DNA rather than specific DNA sequences [42]. Binding stoichiometry between $\mathrm{P} 150_{721-860}$ and 58 bp dsDNA was evaluated in vitro giving a 1:1 molar ratio, in contrast to that observed for Cac-1, which binds an 18 bp dsDNA in a molar ratio of 2:1 (Cac-1:DNA) [38]. Taken together, these findings suggest that WHD from human and yeast may share similarities and differences, as revealed also by the structural comparison of the two proteins. Indeed, a secondary structure prediction of P150 $721-860$, carried out with the online program PHD (accessed date 10 December 2021, https://npsa-prabi.ibcp.fr/cgi-bin/npsa_automat.pl?page = /NPSA/npsa_phd.html), reveals that, although this protein retains the typical elements of the WHD present in Cac-1, significant differences are also present. In particular, $\mathrm{P} 150_{721-860}$ contains a big insertion between predicted helices $\alpha 2$ and $\alpha 3$ with respect to Cac-1 WHD; moreover, it is longer and contains, at the C-terminus, an additional coil region followed by a $\beta$-strand (Figure 5). The observed biochemical and structural differences between the human and the yeast protein could also reflect variations in the mechanism of action, but this topic needs to be further investigated. In this context, it is also worth noting that the full-length P150 contains an additional sequence (residues 861-956) whose function has to be completely unveiled (Figure 1).

A

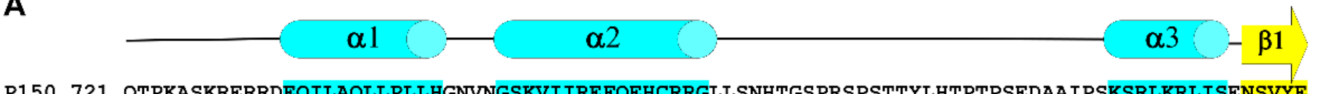

P150 721 QTPKASKRERRDEOILAOLLPLLHGNVNGSKVIIREFOEHCRRGLLSNHTGSPRSPSTTYLHTPTPSEDAAIPSKSRLKRLISENSVYE

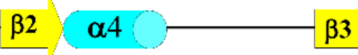

P150 809 KRPDFRMCWYVHPQVLQSFQQEHLPVPCQWSYVTSVPSAPKEDSGSVPSTG

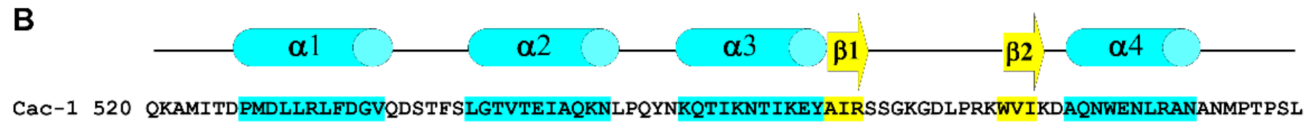

Figure 5. Schematic representation of $\mathrm{P} 150$ and Cac-1 WHD secondary structure. Helices and strands of P150 WHD (A) have been predicted by the PHD program, whereas those of Cac-1 WHD (B) have been calculated with Whatcheck [78] using the crystallographic coordinates (PDB accession code 5JBM) [48]. Helices and strands are represented as cyan cylinders and yellow arrows, respectively. Primary sequences are also shown.

The binding ability of $\mathrm{P} 150_{721-860}$ to DNA is modulated by an acidic region which precedes the WHD. Accordingly, an enlarged construct comprehensive of the ED-rich region, namely $\mathrm{P} 150_{575-860}$, is not able to bind DNA. It is assumed that the negatively charged residues of the ED domain sequestrate the WHD, making it inaccessible to DNA 
binding [43]. Similarly to what happens in yeast, it can be hypothesized that in the whole human CAF-1 complex, the presence of H3-H4 histones, which engages the acidic ED domain, makes the WHD free to interact with DNA [43].

In conclusion, we investigated, for the first time, the biochemical and structural features of the P150 $0_{721-860}$ DNA binding region. Results indicated the typical features of a WHD containing both alpha and beta secondary structure elements. P150 $721-860$ directly interacts with dsDNA [43] in vitro and its binding is modulated by the presence of an acidic stretch encompassing region 575-720. The detected protein/DNA binding ratio is 1:1, different from what was observed in yeast, and this could be indicative of a different mechanism of action between the human and the yeast protein in vivo. This hypothesis is supported by the presence in P150 of a C-terminal region which is completely absent in the yeast homologue and whose role still needs to be defined. Further experiments are currently underway in our lab to provide insights into this C-terminal region

\section{Materials and Methods}

\subsection{P150721-860 and P150575-860 Design, Cloning, Expression, and Purification}

P150721-860 and P150 $575-860$ cDNAs (GeneArt, ThermoFisher Scientific), optimized for expression in E. coli, were amplified by PCR using forward and reverse primers as listed in Table 1. Amplified cDNAs were cloned into pETM13 vector (kind gift from EMBL Heidelberg) using NcoI and XhoI enzymes (New England Biolabs, NEB). This vector was chosen for its feature to encode a six-histidine tag (His-tag) at the C-terminus. The integrity of the sequence was assessed by DNA sequencing upon appropriate digestion with restriction enzymes.

Table 1. List of the primers with the restriction site underlined.

\begin{tabular}{crr}
\hline Name of the Construct & & Primers (F: Forward; R: Reverse) \\
\hline $\mathrm{P} 150_{721-860}$ & $\mathrm{~F}$ & CGCGCGCCATGGGCCAGACCCCGAAAGCAAGC \\
\cline { 2 - 3 } & $\mathrm{R}$ & CGCGCGCTCGAGACCGGTGCTCGGAACG \\
\hline \multirow{2}{*}{$150_{575-860}$} & $\mathrm{~F}$ & CGCGCGCCATGGGCAACAAAAAAACCGCACTGATTCGTG \\
\cline { 2 - 3 } & $\mathrm{R}$ & CGCGCGCTCGAGACCGGTGCTCGGAACG \\
\hline
\end{tabular}

Each recombinant protein $\left(\mathrm{P}_{150_{721-860}}\right.$ or $\left.\mathrm{P} 150_{575-860}\right)$ was expressed by transforming E. coli BL21(DE3)pLysS strain (kind gift from EMBL Heidelberg) with the corresponding plasmid. Cells were grown in LB and induced with $1 \mathrm{mM} \mathrm{IPTG}$ at $16^{\circ} \mathrm{C}$ or $22{ }^{\circ} \mathrm{C}$ for the expression of $\mathrm{P} 150_{721-860}$ and $\mathrm{P} 150_{575-860}$, respectively. After an overnight culture, cells were pelleted by centrifugation (7500 $\mathrm{rpm}$ for $20 \mathrm{~min}$ at $4{ }^{\circ} \mathrm{C}$ ). Identically for both proteins, pellets were resuspended in $20 \mathrm{mM}$ Tris- $\mathrm{HCl}, 500 \mathrm{mM} \mathrm{NaCl}, \mathrm{pH} 7.5$ supplemented with PMSF (1 mM), DNaseI $(5 \mu \mathrm{g} / \mathrm{mL})$, lysozyme $(0.1 \mathrm{mg} / \mathrm{mL})$, and $1 \mu \mathrm{g} / \mathrm{mL}$ of the following protease inhibitors (aprotinin, leupeptin, and pepstatin). Cells were then sonicated on ice and centrifuged $\left(13,500 \mathrm{rpm}\right.$ for $20 \mathrm{~min}$ at $\left.4{ }^{\circ} \mathrm{C}\right)$. Supernatant was purified at room temperature on ÄKTA FPLC (GE Healthcare). P150 $721-860$ was purified by two affinity chromatography steps (TALON and heparin) and a Superdex 75 size exclusion chromatography (SEC), while P150575-860 purification consisted of a TALON affinity chromatography and SEC. Protein quality was assessed by $20 \%$ SDS-PAGE and ESI-TOF MS analysis (Agilent Technologies, Cernusco Sul Naviglio, Italy). Deconvolution was carried out by means of the Agilent MassHunter Qualitative software.

\subsection{ESI-TOF-MS Analyses}

A C4 Biobasic $50 \times 2.1 \mathrm{~mm}$ ID column (ThermoFisher Monza, Italy) was used to load P150 $721-860$ and P150 $1575-860$ proteins with a flowrate of $0.2 \mathrm{~mL} / \mathrm{min}$. ESI-TOF-MS analyses were carried out on an Agilent 1290 Infinity LC System coupled to an Agilent 6230 time-of-flight (TOF) LC/MS system (Agilent Technologies, Cernusco Sul Naviglio, Italy). 
The LC module Agilent 1290 was coupled to a photodiode array (PDA) detector and a 6230 time-of-flight MS detector, along with a binary solvent pump degasser, column heater, and autosampler. Chromatographic separation was performed using, as solvent A, 0.01\% TFA in $\mathrm{H}_{2} \mathrm{O}(v / v)$, and as solvent $\mathrm{B}, 0.01 \%$ TFA in $\mathrm{CH}_{3} \mathrm{CN}(v / v)$. A fully reduced sample with $10 \mathrm{mM}$ DTT was also analyzed. Deconvolution was carried out by means of the Agilent MassHunter Qualitative software.

\subsection{Circular Dichroism}

Circular dichroism (CD) experiments were carried out as previously described $[79,80]$. Spectra were recorded using a Jasco J-815 spectropolarimeter (Jasco, Essex, UK), equipped with a Peltier temperature control system in the far-UV range 190-260 nm. Measurements were run at $20{ }^{\circ} \mathrm{C}$ with three accumulations, using a $1 \mathrm{~mm}$ quartz cell. Experiments were performed using $7 \mu \mathrm{M}$ of $\mathrm{P} 150_{721-860}$ in $1 \mathrm{mM}$ Tris- $\mathrm{HCl}, \mathrm{pH} 7.5$. Raw spectra were corrected for buffer contribution, converted to mean molar ellipticity per residue $(\theta)$ (deg $\mathrm{cm}^{2} \mathrm{dmol}^{-1}$ ), and visualized using GraphPad software. For thermal stability experiments, $\mathrm{P} 150_{721-860}$ was heated from 20 to $100^{\circ} \mathrm{C}$ with a temperature increase of $1^{\circ} \mathrm{C} / \mathrm{min}$ and spectrum recorded at $222 \mathrm{~nm}$, as above described. The molar ellipticity values at $222 \mathrm{~nm}$ were plotted as function of the temperature using GraphPad software. Additionally, the three spectra $\left(5^{\circ} \mathrm{C}, 90^{\circ} \mathrm{C}\right.$, and $5^{\circ} \mathrm{C}$ after heating) were recorded as previously described once the fixed temperature was reached within $\pm 0.1^{\circ} \mathrm{C}$ set by a Peltier device.

\subsection{Light Scattering}

SEC-MALS-QELS (size exclusion chromatography-multi-angle light-scattering-quasielastic light scattering) analyses were carried out as previously described [81]. Briefly, the sample was loaded on a Superdex 75 10/300 GL (GE Healthcare) mounted in line with a multi-angle detector (mini-DAWN TREOS, Wyatt Technology) and a refraction index detector (Shodex RI 101). The first two runs were performed by injecting either P150 ${ }_{721-860}$ or $58 \mathrm{dsDNA}, 475 \mu \mathrm{g}$ and $330 \mu \mathrm{g}$, respectively. The third run consisted of mixing together the previously mentioned quantities achieving a 3.2:1 molar ratio (protein: DNA) incubating the mixture on ice for $45 \mathrm{~min}$ before loading the column. Runs were performed in $20 \mathrm{mM}$ Tris- $\mathrm{HCl}, 150 \mathrm{mM} \mathrm{NaCl}$, and $\mathrm{pH} 7.5$ at room temperature. When specified, LS was carried out in $20 \mathrm{mM}$ Tris- $\mathrm{HCl}, 500 \mathrm{mM} \mathrm{NaCl}, \mathrm{pH}$ 7.5. Data analysis was carried out using ASTRA 5.3.4.14 software (Wyatt Technology Corporation).

\subsection{Electrophoretic Mobility Shift Assay}

The 16 and 58 bp oligonucleotides (Table 2) used for binding assays were from Stazione Zoologica Anton Dohrn (Naples, Italy). Two strands of complementary ssDNA were annealed in $10 \mathrm{mM}$ Tris- $\mathrm{HCl}, 50 \mathrm{mM} \mathrm{NaCl}, 1 \mathrm{mM}$ EDTA, and Ph 7.5 buffer to form dsDNA. Protein dilutions were mixed with dsDNA in $20 \mathrm{Mm}$ Tris- $\mathrm{HCl}, 100 \mathrm{Mm} \mathrm{NaCl}, 1 \mathrm{Mm}$ DTT, and $\mathrm{pH}$ 7.5. In detail, when staining with ethidium bromide (EtBr) (Sigma), $21 \mu \mathrm{M}$ of $16 \mathrm{pb}$ dsDNA were mixed with $\mathrm{P} 150_{721-860}$ in 0-15 molar ratio. Similar quantities were used in the AT- and GC-rich binding experiments. In the case of $58 \mathrm{dsDNA}, 2 \mu \mathrm{M}$ of DNA were mixed with $\mathrm{P} 150_{721-860}$ or $\mathrm{P} 150_{575-860}$ in 0-25 molar ratio. When staining with Sybr Gold, $1 \mu \mathrm{M}$ of dsDNA was mixed with $\mathrm{P} 150_{721-860}$ in 0-80 molar ratio. Binding reaction was incubated 45 min on ice. Gel loading dye, purple (6X, no SDS, New England Biolabs) and glycerol (final concentration of $5 \%$ ), were added to the mixture, prior to the loading into a $6 \%$ PAGE pre-run in $0.5 \mathrm{X}$ TBE buffer. The pre-run and the run were performed at $75 \mathrm{~V}$ on ice, for 30 and $45 \mathrm{~min}$, respectively. Gels were stained either with ethidium bromide (EtBr) or with Sybr Gold (Thermofisher) prior to visualization with UV light. Each fraction bound was calculated by quantifying the density of each lane by ImageJ [82]. The obtained data were analyzed by nonlinear regression equation with hill slope using the GraphPad Software. Results come from at least three experiments. 
Table 2. List of single-strand DNA sequences.

\begin{tabular}{ll}
\hline DNA Length & Sequence $\left(\mathbf{5}^{\prime} \mathbf{- 3}^{\prime}\right)$ \\
\hline $16 \mathrm{bp}$ & TGCTACCGATCGATAC \\
\hline $16 \mathrm{bp}$ GC rich & ATCGCCCGCGCACGCA \\
\hline $16 \mathrm{bp}$ AT rich & ATAATCGATATTCGTT \\
\hline $58 \mathrm{bp}$ & ATACATTTTATGACTGGAAACTTTTTTGTACAA \\
\hline
\end{tabular}

Supplementary Materials: The following supporting information can be downloaded at: https: //www.mdpi.com/article/10.3390/ijms23042160/s1.

Author Contributions: S.M.M., G.D.S. and J.A. conceived the manuscript; S.M.M. and G.D.S. wrote the manuscript, J.A. performed the experiments; all authors prepared the figures. J.A., M.B. and A.D.F. conceived and participated in revision of the paper. All authors commented on the manuscript. All authors have read and agreed to the published version of the manuscript.

Funding: This research was funded by MIUR-PRIN2017 (grant 201744BN5T), MIUR-PON “Ricerca e Innovazione" 2014-2020 (grant MOLIM ONCOBRAIN LAB) and Regione Campania PO FESR 2014-2020 (grant eMORFORAD). J.A. is supported by INCIPIT international PhD program cofounded by Marie Sklodowska-Curie Actions (Horizon 2020).

Institutional Review Board Statement: Not applicable.

Informed Consent Statement: Not applicable.

Acknowledgments: We are grateful to Maurizio Amendola for technical assistance and Florinda Pignatiello for administrative project support.

Conflicts of Interest: The authors declare no conflict of interest.

\section{References}

1. Luger, K.; Dechassa, M.L.; Tremethick, D.J. New insights into nucleosome and chromatin structure: An ordered state or a disordered affair? Nat. Rev. Mol. Cell Biol. 2012, 13, 436-447. [CrossRef]

2. Annunziato, A. DNA packaging: Nucleosomes and Chromatin. Nat. Educ. 2008, 1, 26.

3. Luger, K.; Mäder, A.W.; Richmond, R.K.; Sargent, D.F.; Richmond, T.J. Crystal structure of the nucleosome core particle at $2.8 \AA$ resolution. Nature 1997, 389, 251-260. [CrossRef] [PubMed]

4. McGinty, R.K.; Tan, S. Histone, Nucleosome, and Chromatin Structure. In Fundamentals of Chromatin; Workman, J.L., Abmayr, S.M., Eds.; Springer: New York, NY, USA, 2014; pp. 1-28. ISBN 978-1-4614-8624-4.

5. McGinty, R.K.; Tan, S. Nucleosome Structure and Function. Chem. Rev. 2015, 115, 2255-2273. [CrossRef] [PubMed]

6. Widom, J. Structure, dynamics, and function of chromatin in vitro. Annu. Rev. Biophys. Biomol. Struct. 1998, 27, 285-327. [CrossRef] [PubMed]

7. Li, G.; Levitus, M.; Bustamante, C.; Widom, J. Rapid spontaneous accessibility of nucleosomal DNA. Nat. Struct. Mol. Biol. 2005, 12, 46-53. [CrossRef] [PubMed]

8. Luger, K. Dynamic nucleosomes. Chromosom. Res. 2006, 14, 5-16. [CrossRef]

9. Loyola, A.; Almouzni, G. Histone chaperones, a supporting role in the limelight. Biochim. Biophys. Acta-Gene Struct. Expr. 2004, 1677, 3-11. [CrossRef]

10. Das, C.; Tyler, J.K.; Churchill, M.E.A. The histone shuffle: Histone chaperones in an energetic dance. Trends Biochem. Sci. 2010, 35, 476-489. [CrossRef]

11. Avvakumov, N.; Nourani, A.; Côté, J. Histone Chaperones: Modulators of Chromatin Marks. Mol. Cell 2011, 41, 502-514. [CrossRef]

12. Elsässer, S.J.; D’Arcy, S. Towards a mechanism for histone chaperones. Biochim. Biophys. Acta 2013, 1819, 211-221. [CrossRef]

13. Laskey, R.A.; Honda, B.M.; Mills, A.D.; Finch, J.T. Nucleosomes are assembled by an acidic protein which binds histones and transfers them to DNA. Nature 1978, 275, 416-420. [CrossRef]

14. Laskey, R.A.; Earnshaw, W.C. Nucleosome assembly. Nature 1980, 286, 763-767. [CrossRef]

15. Smith, S.; Stillman, B. Stepwise assembly of chromatin during DNA replication in vitro. EMBO J. 1991, 10, 971-980. [CrossRef]

16. Krude, T. Chromatin: Nucleosome assembly during DNA replication. Curr. Biol. 1995, 5, 1232-1234. [CrossRef]

17. Smith, S.; Stillman, B. Purification and characterization of CAF-I, a human cell factor required for chromatin assembly during DNA replication in vitro. Cell 1989, 58, 15-25. [CrossRef] 
18. Kadyrova, L.Y.; Rodriges Blanko, E.; Kadyrov, F.A. Human CAF-1-dependent nucleosome assembly in a defined system. Cell Cycle 2013, 12, 3286-3297. [CrossRef] [PubMed]

19. Ruiz-Carrillo, A.; Wangh, L.J.; Allfrey, V.G. Processing of newly synthesized histone molecules. Science 1975, 190, 117-128 [CrossRef] [PubMed]

20. Stillman, B. Chromatin assembly during SV40 DNA replication in vitro. Cell 1986, 45, 555-565. [CrossRef]

21. Kamakaka, R.T.; Bulger, M.; Kaufman, P.D.; Stillman, B.; Kadonaga, J.T. Postreplicative chromatin assembly by Drosophila and human chromatin assembly factor 1. Mol. Cell. Biol. 1996, 16, 810-817. [CrossRef]

22. Quivy, J.P.; Grandi, P.; Almouzni, G. Dimerization of the largest subunit of chromatin assembly factor 1: Importance in vitro and during Xenopus early development. EMBO J. 2001, 20, 2015-2027. [CrossRef] [PubMed]

23. Takami, Y.; Ono, T.; Fukagawa, T.; Shibahara, K.; Nakayama, T. Essential role of chromatin assembly factor-1-mediated rapid nucleosome assembly for DNA replication and cell division in vertebrate cells. Mol. Biol. Cell 2007, 18, 129-141. [CrossRef] [PubMed]

24. Quivy, J.P.; Gérard, A.; Cook, A.J.L.; Roche, D.; Almouzni, G. The HP1-p150/CAF-1 interaction is required for pericentric heterochromatin replication and S-phase progression in mouse cells. Nat. Struct. Mol. Biol. 2008, 15, 972-979. [CrossRef] [PubMed]

25. Quivy, J.P.; Roche, D.; Kirschner, D.; Tagami, H.; Nakatani, Y.; Almouzni, G. A CAF-1 dependent pool of HP1 during heterochromatin duplication. EMBO J. 2004, 23, 3516-3526. [CrossRef] [PubMed]

26. Tchénio, T.; Casella, J.-F.; Heidmann, T. A Truncated Form of the Human CAF-1 p150 Subunit Impairs the Maintenance of Transcriptional Gene Silencing in Mammalian Cells. Mol. Cell. Biol. 2001, 21, 1953-1961. [CrossRef]

27. Smith, C.L.; Matheson, T.D.; Trombly, D.J.; Sun, X.; Campeau, E.; Han, X.; Yates, J.R.; Kaufman, P.D. A separable domain of the p150 subunit of human chromatin assembly factor-1 promotes protein and chromosome associations with nucleoli. Mol. Biol. Cell 2014, 25, 2866-2881. [CrossRef]

28. Polo, S.E.; Theocharis, S.E.; Grandin, L.; Gambotti, L.; Antoni, G.; Savignoni, A.; Asselain, B.; Patsouris, E.; Almouzni, G. Clinical significance and prognostic value of chromatin assembly factor-1 overexpression in human solid tumours. Histopathology 2010, 57, 716-724. [CrossRef]

29. Staibano, S.; Mascolo, M.; Mancini, F.P.; Kisslinger, A.; Salvatore, G.; Di Benedetto, M.; Chieffi, P.; Altieri, V.; Prezioso, D.; Ilardi, G.; et al. Overexpression of chromatin assembly factor-1 (CAF-1) p60 is predictive of adverse behaviour of prostatic cancer. Histopathology 2009, 54, 580-589. [CrossRef]

30. Mascolo, M.; Vecchione, M.L.; Ilardi, G.; Scalvenzi, M.; Molea, G.; Di Benedetto, M.; Nugnes, L.; Siano, M.; De Rosa, G.; Staibano, S. Overexpression of Chromatin Assembly Factor-1/p60 helps to predict the prognosis of melanoma patients. BMC Cancer 2010, 10, 63. [CrossRef]

31. Barbieri, E.; De Preter, K.; Capasso, M.; Chen, Z.; Hsu, D.M.; Tonini, G.P.; Lefever, S.; Hicks, J.; Versteeg, R.; Pession, A.; et al. Histone chaperone CHAF1A inhibits differentiation and promotes aggressive neuroblastoma. Cancer Res. 2014, 74, 765-774. [CrossRef]

32. Burgess, R.J.; Zhang, Z. Histone chaperones in nucleosome assembly and human disease. Nat. Struct. Mol. Biol. 2013, 20, 14-22. [CrossRef]

33. Tyler, J.K.; Collins, K.A.; Prasad-Sinha, J.; Amiott, E.; Bulger, M.; Harte, P.J.; Kobayashi, R.; Kadonaga, J.T. Interaction between the Drosophila CAF-1 and ASF1 Chromatin Assembly Factors. Mol. Cell. Biol. 2001, 21, 6574-6584. [CrossRef]

34. Song, Y.; He, F.; Xie, G.; Guo, X.; Xu, Y.; Chen, Y.; Liang, X.; Stagljar, I.; Egli, D.; Ma, J.; et al. CAF-1 is essential for Drosophila development and involved in the maintenance of epigenetic memory. Dev. Biol. 2007, 311, 213-222. [CrossRef]

35. Kaufman, P.D.; Kobayashi, R.; Stillman, B. Ultraviolet radiation sensitivity and reduction of telomeric silencing in Saccharomyces cerevisiae cells lacking chromatin assembly factor-I. Genes Dev. 1997, 1, 345-357. [CrossRef] [PubMed]

36. Sauer, P.V.; Timm, J.; Liu, D.; Sitbon, D.; Boeri-Erba, E.; Velours, C.; Mücke, N.; Langowski, J.; Ochsenbein, F.; Almouzni, G.; et al Insights into the molecular architecture and histone $\mathrm{H} 3-\mathrm{H} 4$ deposition mechanism of yeast Chromatin assembly factor 1. eLife 2017, 6, e23474. [CrossRef]

37. Mattiroli, F.; Gu, Y.; Balsbaugh, J.L.; Ahn, N.G.; Luger, K. The Cac2 subunit is essential for productive histone binding and nucleosome assembly in CAF-1. Sci. Rep. 2017, 7, 46274. [CrossRef] [PubMed]

38. Mattiroli, F.; Gu, Y.; Yadav, T.; Balsbaugh, J.L.; Harris, M.R.; Findlay, E.S.; Liu, Y.; Radebaugh, C.A.; Stargell, L.A.; Ahn, N.G.; et al. DNA-mediated association of two histone-bound complexes of yeast Chromatin Assembly Factor-1 (CAF-1) drives tetrasome assembly in the wake of DNA replication. eLife 2017, 6, e22799. [CrossRef] [PubMed]

39. Krawitz, D.C.; Kama, T.; Kaufman, P.D. Chromatin assembly factor I mutants defective for PCNA binding require Asf1/Hir proteins for silencing. Mol. Cell. Biol. 2002, 22, 614-625. [CrossRef] [PubMed]

40. Ben-Shahar, T.R.; Castillo, A.G.; Osborne, M.J.; Borden, K.L.B.; Kornblatt, J.; Verreault, A. Two Fundamentally Distinct PCNA Interaction Peptides Contribute to Chromatin Assembly Factor 1 Function. Mol. Cell. Biol. 2009, 9, 6353-6365. [CrossRef]

41. Moggs, J.G.; Grandi, P.; Quivy, J.-P.; Jónsson, Z.O.; Hübscher, U.; Becker, P.B.; Almouzni, G. A CAF-1-PCNA-Mediated Chromatin Assembly Pathway Triggered by Sensing DNA Damage. Mol. Cell. Biol. 2000, 20, 1206-1218. [CrossRef]

42. Zhang, K.; Gao, Y.; Li, J.; Burgess, R.; Han, J.; Liang, H.; Zhang, Z.; Liu, Y. A DNA binding winged helix domain in CAF-1 functions with PCNA to stabilize CAF-1 at replication forks. Nucleic Acids Res. 2016, 44, 5083-5094. [CrossRef] 
43. Panne, D.; Sauer, P.V.; Gu, Y.; Liu, W.H.; Mattiroli, F.; Luger, K.; Churchill, M.E.A. Mechanistic insights into histone deposition and nucleosome assembly by the chromatin assembly factor-1. Nucleic Acids Res. 2018, 46, 9907-9917. [CrossRef]

44. Pike, A.C.W.; Shrestha, B.; Popuri, V.; Burgess-Brown, N.; Muzzolini, L.; Costantini, S.; Vindigni, A.; Gileadi, O. Structure of the human RECQ1 helicase reveals a putative strand-separation pin. Proc. Natl. Acad. Sci. USA 2009, 106, 1039-1044. [CrossRef] [PubMed]

45. Gajiwala, K.S.; Chen, H.; Cornille, F.; Roques, B.P.; Reith, W.; Mach, B.; Burley, S.K. Structure of the winged-helix protein hRFX1 reveals a new mode of DNA binding. Nature 2000, 403, 916-921. [CrossRef] [PubMed]

46. Zheng, N.; Fraenkel, E.; Pabo, C.O.; Pavletich, N.P. Structural basis of DNA recognition by the heterodimeric cell cycle transcription factor E2F-DP. Genes Dev. 1999, 13, 666-674. [CrossRef] [PubMed]

47. Kitano, K.; Kim, S.Y.; Hakoshima, T. Structural Basis for DNA Strand Separation by the Unconventional Winged-Helix Domain of RecQ Helicase WRN. Structure 2010, 18, 177-187. [CrossRef] [PubMed]

48. Liu, W.H.; Roemer, S.C.; Zhou, Y.; Shen, Z.-J.; Dennehey, B.K.; Balsbaugh, J.L.; Liddle, J.C.; Nemkov, T.; Ahn, N.G.; Hansen, K.C.; et al. The Cac1 subunit of histone chaperone CAF-1 organizes CAF-1-H3/H4 architecture and tetramerizes histones. eLife 2016, 5, 18023. [CrossRef]

49. Chu, X.; Wang, Y.; Gan, L.; Bai, Y.; Han, W.; Wang, E.; Wang, J. Importance of electrostatic interactions in the association of intrinsically disordered histone chaperone Chz1 and histone H2A.Z-H2B. PLoS Comput. Biol. 2012, 8, e1002608. [CrossRef]

50. Ramos, I.; Fernández-Rivero, N.; Arranz, R.; Aloria, K.; Finn, R.; Arizmendi, J.M.; Ausió, J.; Valpuesta, J.M.; Muga, A.; Prado, A. The intrinsically disordered distal face of nucleoplasmin recognizes distinct oligomerization states of histones. Nucleic Acids Res. 2014, 42, 1311-1325. [CrossRef]

51. Kaufman, P.D.; Kobayashi, R.; Kessler, N.; Stillman, B. The p150 and p60 subunits of chromatin assemblyfactor I: A molecular link between newly synthesized histories and DNA replication. Cell 1995, 81, 1105-1114. [CrossRef]

52. Dong, H.; Lin, W.; Zhang, C.K.; Xiong, H.; Fu, G.; Jin, W.R.; Chen, R.; Chen, Z.; Qi, Z.T.; Huang, G.M. Genomic sequence and expression analyses of human chromatin assembly factor 1 p150 gene. Gene 2001, 264, 187-196. [CrossRef]

53. Keller, C.; Krude, T. Requirement of cyclin/Cdk2 and protein phosphatase 1 activity for chromatin assembly factor 1-dependent chromatin assembly during DNA synthesis. Biol. Chem. 2000, 275, 35512-35521. [CrossRef] [PubMed]

54. Volk, A.; Crispino, J.D. The role of the chromatin assembly complex (CAF-1) and its p60 subunit (CHAF1b) in homeostasis and disease. Biochim. Biophys. Acta-Gene Regul. Mech. 2015, 1849, 979-986. [CrossRef] [PubMed]

55. Thiru, A.; Nietlispach, D.; Mott, H.R.; Okuwaki, M.; Lyon, D.; Nielsen, P.R.; Hirshberg, M.; Verreault, A.; Murzina, N.V.; Laue, E.D. Structural basis of HP1/PXVXL motif peptide interactions and HP1 localisation to heterochromatin. EMBO J. 2004, 23, 489-499. [CrossRef] [PubMed]

56. Lomberk, G.; Wallrath, L.L.; Urrutia, R. The Heterochromatin Protein 1 family. Genome Biol. 2006, 7, 228. [CrossRef] [PubMed]

57. Reese, B.E.; Bachman, K.E.; Baylin, S.B.; Rountree, M.R. The Methyl-CpG Binding Protein MBD1 Interacts with the p150 Subunit of Chromatin Assembly Factor 1. Mol. Cell. Biol. 2003, 23, 3226-3236. [CrossRef]

58. Geiss-Friedlander, R.; Melchior, F. Concepts in sumoylation: A decade on. Nat. Rev. Mol. Cell Biol. 2007, 8, 947-956. [CrossRef]

59. Shibahara, K.I.; Stillman, B. Replication-dependent marking of DNA by PCNA facilitates CAF-1-coupled inheritance of chromatin. Cell 1999, 96, 575-585. [CrossRef]

60. Ramakrishnan, V.; Finch, J.T.; Graziano, V.; Lee, P.L.; Sweet, R.M. Crystal structure of globular domain of histone H5 and its implications for nucleosome binding. Nature 1993, 362, 219-223. [CrossRef]

61. Clark, K.L.; Halay, E.D.; Lai, E.; Burley, S.K. Co-crystal structure of the HNF-3/fork head DNA-recognition motif resembles histone H5. Nature 1993, 364, 412-420. [CrossRef]

62. Over, R.S.; Michaels, S.D. Open and closed: The roles of linker histones in plants and animals. Mol. Plant 2014, 7, 481-491. [CrossRef] [PubMed]

63. Kelley, L.A.; Mezulis, S.; Yates, C.M.; Wass, M.N.; Sternberg, M.J.E. The Phyre2 web portal for protein modeling, prediction and analysis. Nat. Protoc. 2015, 10, 845-858. [CrossRef] [PubMed]

64. Takahashi, T.S.; Sato, Y.; Yamagata, A.; Goto-Ito, S.; Saijo, M.; Fukai, S. Structural basis of ubiquitin recognition by the winged-helix domain of Cockayne syndrome group B protein. Nucleic Acids Res. 2019, 47, 3784-3794. [CrossRef] [PubMed]

65. Liao, Y.-D.; Jeng, J.-C.; Wang, C.-F.; Wang, S.-C.; Chang, S.-T. Removal of N-terminal methionine from recombinant proteins by engineered E. coli methionine aminopeptidase. Protein Sci. 2004, 13, 1802-1810. [CrossRef] [PubMed]

66. Hirel, P.H.; Schmitter, J.M.; Dessen, P.; Fayat, G.; Blanquet, S. Extent of N-terminal methionine excision from Escherichia coli proteins is governed by the side-chain length of the penultimate amino acid. Proc. Natl. Acad. Sci. USA 1989, 86, 8247-8251. [CrossRef]

67. Chaudhuri, T.K.; Horii, K.; Yoda, T.; Arai, M.; Nagata, S.; Terada, T.P.; Uchiyama, H.; Ikura, T.; Tsumoto, K.; Kataoka, H.; et al Effect of the extra N-terminal methionine residue on the stability and folding of recombinant $\alpha$-lactalbumin expressed in Escherichia coli. J. Mol. Biol. 1999, 285, 1179-1194. [CrossRef]

68. Janes, R.W. PDB2CD visualises dynamics within protein structures. Eur. Biophys. J. 2017, 46, 607-616. [CrossRef]

69. Teichmann, M.; Dumay-Odelot, H.; Fribourg, S. Structural and functional aspects of winged-helix domains at the core of transcription initiation complexes. Transcription 2012, 3, 2-7. [CrossRef] 
70. Bulatov, E.; Martin, E.M.; Chatterjee, S.; Knebel, A.; Shimamura, S.; Konijnenberg, A.; Johnson, C.; Zinn, N.; Grandi, P.; Sobott, F; et al. Biophysical studies on interactions and assembly of full-size E3 ubiquitin ligase: Suppressor of cytokine signaling 2 (SOCS2)-elongin BC-cullin 5-ring box protein 2 (RBX2). J. Biol. Chem. 2015, 290, 4178-4191. [CrossRef]

71. Ceschini, S.; Lupidi, G.; Coletta, M.; Pon, C.L.; Fioretti, E.; Angeletti, M. Multimeric self-assembly equilibria involving the histone-like protein H-NS. A thermodynamic study. J. Biol. Chem. 2000, 275, 729-734. [CrossRef]

72. Valenzuela-Soto, E.M.; Velasco-García, R.; Mújica-Jiménez, C.; Gaviria-González, L.L.; Muñoz-Clares, R.A. Monovalent cations requirements for the stability of betaine aldehyde dehydrogenase from Pseudomonas aeruginosa, porcine kidney and amaranth leaves. Chem.-Biol. Interact. 2003, 143-144, 139-148. [CrossRef]

73. Groth, A.; Rocha, W.; Verreault, A.; Almouzni, G. Chromatin Challenges during DNA Replication and Repair. Cell 2007, 128, 721-733. [CrossRef]

74. Hoek, M.; Stillman, B. Chromatin assembly factor 1 is essential and couples chromatin assembly to DNA replication in vivo. Proc. Natl. Acad. Sci. USA 2003, 100, 12183-12188. [CrossRef]

75. Chen, Y.; Wan, B.; Wang, K.C.; Cao, F.; Yang, Y.; Protacio, A.; Dou, Y.; Chang, H.Y.; Lei, M. Crystal structure of the N-terminal region of human Ash2L shows a winged-helix motif involved in DNA binding. EMBO Rep. 2011, 12, 797-803. [CrossRef]

76. Littler, D.R.; Alvarez-Fernández, M.; Stein, A.; Hibbert, R.G.; Heidebrecht, T.; Aloy, P.; Medema, R.H.; Perrakis, A. Structure of the FoxM1 DNA-recognition domain bound to a promoter sequence. Nucleic Acids Res. 2010, 38, 4527-4538. [CrossRef]

77. Liu, Y.; Huang, H.; Zhou, B.O.; Wang, S.S.; Hu, Y.; Li, X.; Liu, J.; Zang, J.; Niu, L.; Wu, J.; et al. Structural analysis of Rtt106p reveals a DNA binding role required for heterochromatin silencing. J. Biol. Chem. 2010, 285, 4251-4262. [CrossRef]

78. Hooft, R.W.W.; Vriend, G.; Sander, C.; Abola, E.E. Errors in protein structures. Nature 1996, 381, 272-272. [CrossRef] [PubMed]

79. Ascione, G.; de Pascale, D.; De Santi, C.; Pedone, C.; Dathan, N.A.; Monti, S.M. Native expression and purification of hormonesensitive lipase from Psychrobacter sp. TA144 enhances protein stability and activity. Biochem. Biophys. Res. Commun. 2012, 420, 542-546. [CrossRef]

80. Buonanno, M.; Langella, E.; Zambrano, N.; Succoio, M.; Sasso, E.; Alterio, V.; Di Fiore, A.; Sandomenico, A.; Supuran, C.T.; Scaloni, A.; et al. Disclosing the Interaction of Carbonic Anhydrase IX with Cullin-Associated NEDD8-Dissociated Protein 1 by Molecular Modeling and Integrated Binding Measurements. ACS Chem. Biol. 2017, 12, 1460-1465. [CrossRef] [PubMed]

81. Langella, E.; Buonanno, M.; Vullo, D.; Dathan, N.; Leone, M.; Supuran, C.T.; De Simone, G.; Monti, S.M. Biochemical, biophysical and molecular dynamics studies on the proteoglycan-like domain of carbonic anhydrase IX. Cell. Mol. Life Sci. 2018, 75, 3283-3296. [CrossRef] [PubMed]

82. Rueden, C.T.; Schindelin, J.; Hiner, M.C.; DeZonia, B.E.; Walter, A.E.; Arena, E.T.; Eliceiri, K.W. ImageJ2: ImageJ for the next generation of scientific image data. BMC Bioinform. 2017, 18, 529. [CrossRef] [PubMed] 